\title{
MENINGKATKAN MINAT BELAJAR ANAK DENGAN MENGGUNAKAN TEKNIK KOLASE DARI BAHAN PLASTIK BEKAS JAJANAN DI TK NEGERI 1 PEMBINA GUNUNGSITOLI SELATAN T.P. 2014/2015
}

\author{
NATALINA PURBA, MARIANA LAROSA
}

STP Sibolga, Taman Kanak-kanak Negeri I Pembina Gunungsitoli, Email: missnataliapurba@gmail.com, mariani_larosa@yahoo.co.id

\begin{abstract}
The purpose of this study is to increase children's interest in learning to use traditional learning collage technique of plastic scrap materials snacks. This study begins October 13, 2014 and ending November 21, 2014, with a research subject as many as 15 children. This study was conducted in TK Negeri Pembina Gunungsitoli 1 South. Research Model action Deny Setiawan, where I cycle consists of four components, covering planning, action, observation and reflection. This study applies two cycles consisting of 10 actions. Analysis of data using qualitative methods. The results of research studies have occurred from the first cycle, $46.68 \%$ of children, including less well, as much as $26.66 \%$, including $26.66 \%$ of criteria as well as very good, while on the second cycle has been a significant increase that $20 \%$ of children included both criteria and $80 \%$ including excellent. Researchers suggest the success of a program requires the role of the competent institution, Master sole spearhead to make innovations in improving the quality of education to the students.
\end{abstract}

Keywords: Interest in Learning Child, Engineering Collage, age 5-6 years

\begin{abstract}
Abstrak: Tujuan penelitian ini adalah meningkatkan minat belajar anak dengan pembelajaran yang mengggunakan teknik kolase dari bahan plastik bekas jajanan. Penelitian ini dimulai 13 Oktober 2014 dan berakhir 21 November 2014, dengan subjek penelitian sebanyak 15 orang anak. Penelitian ini diadakan di TK Negeri 1 Pembina Gunungsitoli Selatan.Penelitiandengan Model tindakan Setiawan Deny, dimana I siklus terdiri dari 4 komponen, meliputi perencanaan, tindakan, pengamatan dan refleksi. Penelitian ini berlaku 2 siklus yang terdiri atas 10 tindakan. Analisis data menggunakan metode kualitatif. Hasil penelitian telah terjadi penelitian dari siklus I, 46,68\% anak termasuk kurang baik, sebanyak 26,66 \% termasuk kriteria baik serta 26,66\% sangat baik, sedangkan pada siklus II telah terjadi peningkatan yang signifikan bahwa $20 \%$ anak termasuk kriteria baik dan $80 \%$ termasuk sangat baik. Peneliti menyarankankeberhasilan suatu program menuntut adanya peran dari institusi yang berwenang, Guru satu-satunya ujung tombak untuk melakukan inovasi-inovasi dalam meningkatkan kualitas pendidikan kepada anak didik.
\end{abstract}

Kata Kunci : Minat Belajar Anak, Teknik Kolase, Usia 5-6 tahun

Pembelajaran merupakan dan berkeseimbangan suatu kegiatan.

bentuk penyelenggaraan pendidikan

Pembelajaran di TK bersifat spesifik

yang memadukan secara sistematik

didasarkan pada tugas-tugas per 
tumbuhan dan perkembangan yang meliputi moral dan nilai-nilai agama, sosial-emosional, bahasa, kognitif, fisik, motorik, dan seni.

Salah satu kemampuan pada anak TK yang berkembang dengan pesat adalah kemampuan fisik motorik. Motorik adalah semua gerakan yang mungkin dapat dilakukan oleh seluruh tubuh sedangkan perkembangan motorik dapat disebut sebagai perkembangan dari unsur kematangan dan pengendalian gerakan tubuh.

Pembuatan kolase merupa kan bagian dari kegiatan pembelajaran di TK untuk meningkatkan perkembangan motorik halus anak, sehingga dengan kegiatan membuat kolase anak-anak dapat melatih kesabaran, ketelitian, kejelian, kebersamaan, dan terutama melatih koordinasi gerak tangan. koordinasi gerak tangan anak perlu dilatih agar gerakan tangan anak terbiasa dengan hal-hal baik.

$$
\text { Pemanfaatan }
$$

media pembelajaran sangatlah penting dalam memacu kecerdasan anak karena banyak teori menyatakan bahwa anak usia taman kanak-kanak berada pada taraf berpikir konkrit sehingga dalam proses abstrak agar anak lebih tertarik, mereka senang memotivasi, serta menumbuhkan rasa keingintahuannya.

Disadari bahwa dalam kegiatan rutin yang tidak mengacu kepada kebutuhan anak secara individual maupun kelompok akan menciptakan pembelajaran yang membosankan bagi anak. Hal tersebut disebabkan karena dari hari ke hari tetap sama tanpa kegiatan yang menantang dan menarik.

Dalam kegiatannya dengan peningkatan minat anak dalam teknik mengisi kolase dengan menggunakan media yang menarik adalah suatu tantangan bagi penulis untuk sebisa mungkin meminimalisir kondisi anak-anak di TK Negeri I Pembina Gunungsitoli Selatan yang tidak begitu tertarik apabila mereka disuguhkan mengisi kolase dengan bahan yang monoton. Melalui aktifitas menghias dengan biji-bijian atau potongan-potongan kertas, kita dapat mendekorasi permukaan suatu benda dengan menempelkan sesuatu dipermukaannya. 
Menurut Yani Mulyani dan Juliska Gracinia (2007: xiii) Proses keterampilan bagi anak usia Taman Kanak-kanak merupakan kegiatan bermain dan sekaligus berseni dalam kegiatan anak. Sedang bermain adalah naluri pada setiap anak terlebih pada usia dini, yang akhirnya dapat ikut serta berperan dalam mematangkan emosional bagi anak sehingga dapat memenuhi kebutuhan setiap fase perkembangan psikologi anak.

Setelah pengamatan yang serius penulis menemukan beberapa faktor penyebab mengapa anak-anak tidak antusias akan hal tersebut yaitu karena media yang disediakan tidak variatif yakni dengan menggunakan satu jenis media saja sehingga tidak menumbuhkan minat belajar bagi anak bahkan membosankan. Disisi lain berawal dari ketidak semangatan merka sehingga berpengaruh pada penyelesaian pengisian kolase yang memakan waktu sangat lama, ini juga disebabkan karena ukuran kolase yang disediakan terlalu besar, artinya anak-anak merasa bosan $\mathrm{dn}$ terbebani oleh faktor-faktor tersebut.
Minat anak dapat dikembangkan apabila dilakukan dengan metode-metode yang tepat, misalnya dengan perlakuan metode demontrasi dengan tujuan untuk mempengaruhi perhatian anak lebih terarah pada materi yang sedang dipelajari serta pengalaman dan kesan sebagai hasil penambahan lebih melekat pada diri anak. (Bunda Lucy: 2010:97)

Dari uraian di atas dapat disimpulkan bahwa kegiatan kolase anak dapat:
a. Meningkatkan kepercayaan diri
b. Menampilkan kreatifitas
c. Meningkatkan kosentrasi
d. Melatih ketekunan

\section{Indentifikasi Masalah}

Dalam proses dan pelaksanaan kegiatan mengisi kolase pendidik pada umumnya menghadapi masalah dalam penjelasan kegiatan yang sesuai dengan tujuan dan indikator serta cara mengembangkan kegiatan tersebut terlihat dari hasil karya anak yang berbentuk portofolio tidak menunjukan hasil yang baik dalam mengisi 
kolase dari waktu ke waktu melalui proses pelaksanaan kegiatan.

Masalah yang dihadapi anak di TK Negeri 1 Pembina Gunungsitoli Selatan dalam memahami dan memancing minat serta memotivasi pada kegiatan mengisi kolase dengan ukuran kertas yang berbeda dan metode yang memungkinkan guru atau pendidik menciptakan atau merancang kegiatan yang dapat meningkatkan minat anak sehingga anak melakukan kegiatan tesebut dengan baik.

Oleh sebab itu, saya sebagai pendidik mengidentifikasikan masalah:

1. Metode yang digunakan tidak sesuai

2. Materi yang disampaikan membosankan

3. Minat belajar anak sangat rendah

4. Suasana kelas tidak kondusif

5. Media pembelajaran tidak variatif

\section{Analisis Masalah}

Untuk mengatasi hal tersebut, diperlukan strategi pengenbangan yang sesuai dengan karakteristik anak TK dan pengembangannya harus berpijak pada prinsip-prinsip dasar yang hakiki. Pendidikan Taman Kanak-Kanak sebagai sebuah taman bermain, bersosilisasi, dan juga sebagai wahana untuk mengembangkan berbagai kemampuan prakolastik yang lebih substansial.

Srategi yang digunakan pun harus menyediakan dengan tepat sesuai dengan minat yang dibutuhkan anak dan melibatkan anak di setiap kegiatan. Pendekatan disesuaikan dengan karakteristik pembelajaran di TK yakni melalui bermain dengan menggunakan metode mengajar yang tepat untuk mengembangkan minat anak dalam teknik mengisi kolase serta melibatkan anak di dalam kegiatan dan dapat memberi pengalaman yang sangat berharga bagi anak, selain itu perlu memotivasi anak sehingga kedua faktor itu betul-betul memberi pengaruh yang besar dalam pengembangan minat anak dalam teknik mengisi 
kolase dengan menggunakan plastik bekas jajanan.

Untuk meningkatkan minat anak dalam teknik mengisi kolase tidak sesuai dengan harapan saya sebagai guru, semua terlihat dari hasil karya anak yang selalu tidak berhasil. Penyebab masalah mungkin penjelasan yang saya sampaikan kurang dimengerti anak atau media yang saya gunakan kurang tepat serta pengaturan kelas atau duduk anak kurang tepat serta perlu umpan balik dalam setiap selesai kegiatan dengan memamerkan hasil karya anak.

\section{Alternatif dan Prioritas Pemecahan Masalah}

Tindakan yang dapat dijadikan alternatif dan prioritas dalam kegiatan perbaikan ini adalah menjadikan kegiatan mengisi kolase bagi anak merupakan kegiatan yang menarik dan menyenangkan dengan cara menghadirkan bentuk-bentuk binatang yang disenangi anak (Carmer and Murphy: 2006:47)

\section{A. TUJUAN PERBAIKAN}

a. Meningkatkan minat belajar anak dengan pembelajaran yang menggunakan teknik kolase dari bahan plastik bekas jajanan

b. Meningkatkan kemampuan anak untuk mengisi kolase dengan rapi dan tepat waktu.

\section{B. MANFAAT PERBAIKAN}

a. Melatih pengetahuan guru untuk mengevaluasikan kemampuan anak dalam menyiapkan lembar kerja yang tepat pada anak.

b. Menggali kreativitas guru untuk mengembangkan ketrampilan.

c. Melatih kemampuan guru dalam mengkombinasikan beberapa media untuk keberhasilan proses belajar mengajar.

d. Melatih motorik halus pada anak.

e. Melatih kesabaran ketekunan dan kedisplinan. 
f. Menumbuhkan keberanian pada anak.

g. Meningkatkan citra diri dan bakat anak.

h. Menumbuhkan daya imajinasi pada anak.

i. Menumbuhkan daya kreatifitasi pada anak.

\section{KAJIAN PUSTAKA}

\section{A. Kajian Teori}

Salah satu standar kompetensi 2004 di Taman KanakKanak adalah pengembangan fisik motorik pada dasarnya perkembangan motorik merupakan perubahan tingkah laku motorik yang terjadi secara terus menerus sepanjang siklus kehidupan manusia. Pelaksanaan pengembangan kemampuan motorik halus pada anak usia dini dilaksanakan belajar sambil bermain. Prioritas pengembangan kemampuan motorik halus anak adalah mengembangkan kemampuan daya cipta anak, mengembangkan kreatifitas dan mampu mengendalikan emosi, mampu mengkoordinasikan kecepatan tangan dan mata ini sesuai dengan pendapat Hajar Pamadhi, 2008 yang menyatakan bahwa pengembangan motorik halus anak dapat menumbuhkan rasa seni pada anak usia dini.

\section{B. Pengertian Kolase}

Menurut kamus besar Bahasa Indonesia, kolase adalah komposisi artistik yang dibuat dari berbagai bahan (kain, kertas, kayu) yang ditempelkan pada permukaan gambar (Depdiknas 2001,580). Dari defenisi tersebut dapat disimpulkan bahwa kolase, yaitu merupakan karya seni rupa dua dimensi yang menggunakan bahan yang bermacam-macam selama bahan dasar tersebut dapat dipadukan dengan bahan dasar lain yang akhirnya dapat menyatu menjadi karya yang utuh dan dapat mewakili perasaan estestis orang yang membuatnya. Selanjutnya kolase dipahami sebagai suatu teknik seni menempel berbagai macam materi selain cat, seperti kertas, kain, kaca, logam dan lain sebagainya kemudian dikombinasikan dengan penggunaan cat (minyak) atau teknik lainnya (Susanto M, 2002:63). 
Kolase (collage) adalah bisa dipertimbangkan sebagai media penyusunan berbagai macam bahan pada sehelai kertas yang meliputi kegiatan menempel potonganpotongan kertas atau material lain untuk membentuk sebuah desain atau rancangan tertentu (Jim Supangkat, Rizki A Zaelani, 2006:64). Dalam Kamus Modern Art,ACollins Larousse Concise Encyclopedia dikatakan bahwa semua kegiatan 'perakitan' beraneka bahan dasar menjadi sebuah karya seni. Misalnya, merakit dan merekatkan kertas, kayu, metal, barang-barang bekas, bahkan sampah ke dalam media hiasan dinding.

\section{Pengertian Media}

Menurut Heinch, Molenda, dan Russel (1993:4.4) media merupakan saluran komunikasi media berasal dari bahasa latin dan merupakan bentuk jamak dari kata medium yang secara harafiah berarti perantara yaitu, perantara sumber pesan (a source) dengan penerima pesan (a receiver). Mereka mencotohkan media ini dengan film, televisi, diagram, bahan tercetak (printed materials). Komputer, dan instrukter. Contoh media tersebut pembelajaran jika membawa pesanpesan dalam rangka mencapai tujuan pembelajaran.

Media plastik bekas jajanan adalah media yang menggunakan plastik bekas kemasan makanan ringan. Plastik bekas jajanan selama ini hanya dianggap sebagai sampah, dibuang dan dibakar, padahal dapat dimanfaatkan untuk membuat kerajinan tangan yang lain seperti tas, dompet dan hiasan lain.

Dalam situasi pembelajaran di TK terdapat pesan-pesan yang harus dikomunikasikan. Pesan tersebut disampaikan oleh guru kepada anak melalui suatu media dengan menggunakan prosedur pembelajaran tertentu yang di sebut metode. Masih terdapat pengertian lain yang dikemukakan oleh beberapa ahli, diantaranya media diartikan sebagai berikut :

1. Teknologi pembawa pesan yang dimanfaatkan untuk keperluan pembelajaran (schramm, 1997).

2. Sarana fisik untuk menyampaikan isi/materi pembelajaran, seperti buku, film, video, slide (Briggs, 1997). 
3. Sarana komunikasi dalam bentuk cetak maupun pandang dengar termasuk teknologi perangkat kerasnya (NEA,1969). Setelah mencermati beberapa pengertian diatas, ternyata yang disebut media pembelajaran itu selalu terdiri atas dua unsur penting yaitu unsur peralatan atau perangkat keras (hardware) dan unsur pesan (software) adalah informasi atau bahan ajar dalam tema/topic tertentu yang akan disampaikan atau dipelajari anak, sedangkan unsur perangkat keras (hardware) adalah sarana atau peralatan yang digunakan untuk menyajikan pesan tersebut.

Dari beberapa pendapat ahli diatas menunjukkan bahwa media pembelajaran itu sangatlah penting sehingga harus dijadikan sebagai bagian yang tak terpisahkan (integrasi) dalam proses pembelajaran di TK alasannya adalah:
1. Banyak hasil penelitian menunjukkan bahwa proses pembelajaran akan lebih berhasil nilai amat turun aktif dalam proses pembelajaran tersebut. Dengan perkataan ini yang menjadi pusat kegiatan dalam kegiatan pembelajaran bukanlah guru melainkan anak, hal ini mengandung pengertian perlunya sebagai fasilitas belajar, termasuk media pembelajaran.

2. Penelitian yang dilakukan oleh British Audio-visual

association menghasilkan temuan bahwa rata-rata jumlah informasi yang diperoleh seseorang melalui indra menunjukkan komposisi sebagai berikut :

$75 \%$ melalui indra penglihatan (visual)

$13 \%$ melalui pendengaran (auditori)

$6 \%$ melalui indra sentuhan dan perabaan

$6 \%$ melalui indra penciuman

Dari hasil temuan penelitian tersebut dapat diketahui bahwapengetahuan paling 
banyak diperoleh secara visual atau melalui indra penglihatan.

3. Temuan penelitian lainnya menunjukkan bahwa pengetahuan yang dapat diingat seseorang antara lain tergantung pada melalui indra apa ia memperoleh pengetahuannya. Pengetahuan ini mencobakan tiga macam cara menyampaikan inforormasi yaitu secara auditori, visual, dan audiovisual kemudian masingmasing kelompok yang menerima informasi secara berbeda-beda dites daya ingatannya yaitu berapa banyak informasi yang masih diingat setelah 3 jam dan tiga hari.

\section{Karakteristik Anak Usia Dini}

Anak usia dini memiliki karakter yang sangat unik (Habibi: 2015:122), berikut akan kita bahasa satu persatu:

1. Memiliki rasa ingin tahu yang besar.

Anak usia dini sangat tertarik dengan dunia sekitarnya, dia ingin mengetahui segala sesuatu yang terjadi disekelilingnya. Pada masa bayi, ketertarikan ini ditunjukkan dengan meraih dan memasukkannya ke dalam mulut benda apa saja yang berada dalam jangkauan. Pada anak usia 34 tahun. Selain sering membongkar pasang segala sesuatu untuk mengetahui rasa ingin tahunya. Anak juga mulai gemar bertanya meski dalam bahasa yang masih sangat sederhana.

2. Merupakan pribadi yang unik Meskipun banyak terdapat kesamaan dalam pola umum perkembangan setiap anak meskipun kembar memiliki keunikan masing-masing misalnya dalam hal gaya belajar, minat dan latar belakang keluarga.

3. Suka berfantasi dan berimajinasi

Usia dini sangat suka membayangkan dan mengembangkan berbagai hal jauh melampaui kondisi nyata, anak dapat menceritakan berbagai hal 
dengan sangat meyakinkan seolah-olah dia melihat atau mengalaminya sendiri.

4. Masa paling pontesional untuk belajar

Pada masa usia dini sering juga disebut dengan istilah golden age atau usia emas karena pada rentang usia ini mengalami pertumbuhan dan perkembangan yang sangat pesat pada berbagai aspek.

5. Menunjukkan sikap egosentris

Egosentria berasal dari kata ego dan sentries. Ego artinya aku sentries artinya pusat jadi, egosentries artinya "Berpusat pada aku" artinya anak usia dini pada umumnya hanya memahami sesuatu dari sudut pandangannya sendiri, bukan sudut pandang orang lain.

6. Memiliki rentang daya konsentrasi yang pendek

Sering kali kita saksikan bahwa anak usia dini cepat sekali berpindah dari suatu kegiatan ke kegiatan yang lain. Anak usia dini memang mempunyai rentang perhatian yang sangat pendek sehingga perhatiannya mudah teralihkan pada kegiatan lain.

7. Sebagai bagian dari mahkluk sosial Anak usia dini suka suka begaul dan bermain dengan teman sebayanya, ia mulai belajar berbagi, mengalah, dan antri menunggu giliran saat bermain dengan temantemannya.

\section{E. Metode Demonstrasi}

Metode demonstrasi adalah suatu strategi pengembangan dengan cara memberikan pengalaman belajar melalui perbuatan melihat dan mendengarkan yang diikuti dengan meniru pekerjaan yang di demonstrasikan. Metode demonstrasi dapat juga dikatakan sebagai suatu metode untuk memperagakan serangkaian tindakan berupa gerakan yang menggambarkan suatu cara kerja atau urutan proses sebuah peristiwa/kejadian. Biasanya metode demonstrasi ini dipakai untuk membuktikan sesuatu atau gerakan untuk dicontoh. (Anas: 2014:27) 
Metode demonstrasi merupakan suatu metode mengajar dimana seorang guru, orang luar atau manusia sumber yang sengaja diminta atau suatu proses, misalnya bagaimana cara membuat peta timbul, bagaimana cara menggunakan kamera dengan hasil yang baik, dan sebagainya. Menurut Muhibbin Syah (2000:9.2), demonstrasi adalah metode mengajar dengan cara memperagakan barang, kejadian, aturan, dan urutan melakukan suatu kegiatan, baik secara langsung maupun melalui pengggunaan media pengajaranyang relevan dengan pokok bahasan atau materi yang sedang disajikan.

\section{Menurut Syaiful Bahri} Djamarah (2000:48), metode demonstrasi adalah metode yang digunakan untuk memperlihatkan sesuatu proses atau cara kerja suatu benda yang berkenan dengan bahan pelajaran.

Dalam hal ini, guru menunjukkan mengerjakan dan menjelaskan apa yang sedang dilakukannya (showing, doing, telling). Tiga macam perbuatan guru ini merupakan komponen yang utama dalam metode demonstrasi. (Suyano dan Jihad: 2013:128)

Demontrasi dapat dilakukan sebagai imporvisasi maupun dirancang terlebih dahulu. Keduanya sangat efektif dalam kegitan pembelajaran pada anak usia dini. Metode demonstrasi yang dipadukan dengan metode pertemuan, memungkinkan guru membimbing anak menemukan hal-hal yang baru berdasarkan praduga atau Hipotesis yang di susun oleh anak. Dari hasil pembuktian itu anak akan dapat menarik kesimpulan yang berlaku secara umum. Anak-anak membuat praduga dengan menerapkan pengetahuan yang telah di milikinya dan mengujinya pada kegiatan demonstrasi tersebut. (Suyano dan Jihad: 2013:129)

Demonstrasi dapat pula dipadukan dengan metode ekspositorik. Dalam metode ekspositorik guru menyajikan informasi kepada anak dengan cara menjelaskan melalui buku, film atau slide. Guru menjelaskan kepada anak apa yang diharapkan terjadi apabila guru melakukan tindakan tersebut. (Wahdiyani, Zuharni:2010:73) 
Metode demonstrasi bisa juga dilakukan melalui dramatisasi. Dramatisasi banuak dipergunakan dalam bidang bahasa maupun sosial. Berdasarkan hasil penelitian, baik demonstrasi murni (menjelaskan menunjukkan mengerjakan) maupun demonstrasi sebagai kegiatan dramatis merupakan kegiatan yang efektif apabila guru dapat membimbing anak-anak memasuki situasi yang memberikan pengalaman-pengalaman yang menimbulkan kegiatan belajar kepada anak. Pengalaman belajar yang diberikan guru dalam kegiatan demonstrasi harus relevan dengan kehidupan dan ada kesinambungan dengan pengalaman yang lalu maupun dengan pengalaman yang akan datang. ((Wahdiyani, Zuharni:2010:74)

Menurut penulis melalui kegiatan demonstrasi, guru dapat meningkatkan pemahaman anak melalui penglihatan dan pendengaran. Anak diminta untuk memperhatikan dan mendengarkan baik-baik semua keterangan guru sehingga ia lebih paham tentang cara mengerjakan sesuatu. Dengan demikian, selanjutnya anak dapat meniru bagaimana caranya melakukan hal tersebut seperti yang dicontohkan oleh guru.

\section{Manfaat Metode Demonstrasi}

$$
\text { Manfaat psikologis }
$$

pedagogis dari metode demonstrasi secara umum adalah sebagai berikut (Johnson: 2002P161-166) :

a. Perhatikan anak dapat lebih dipusatkan

b. Proses belajar anak lebih terarah pada materi yang sedang dipelajari

c. Pengalaman dan kesan sebagai hasil pembelajaran lebih melekat dalam diri anak.

Manfaat tersebut seirama dengan cara berfikir anak usia dini yang bersifat realistik dan konkret sehingga dapat mempelajari secara langsung dan jelas melalui pengamatannya, selain tentunya juga akan menarik perhatiannya.

Disamping itu , metode demonstrasi memiliki 2 fungsi yaitu sebagai berikut :

a. Dapat dipergunakan untuk memberikan ilustrasi dalam menjelaskan informasi kepada anak. Bagi anak, melihat langsung bagaimana 
sesuatu peristiwa terjadi akan lebih menarik, merangsang perhatian, dan lebih menantang dari pada hanya mendengarkan penjelasan guru. Misalnya, dalam rnilai sosial, moral, dan keagamaan akan lebih berhasil apabila penerapan nilai-nilai tersebut di dramatisasikan dengan menggunakan ilustrasi.

b. Membantu meningkatkan daya pikir anak usia dini terutamanya daya berpikiranak dlam meningkatkan kemampuan mengenal, mengingat, berpikir konvergan, dan berpikir evauative. Pengembangan daya pikir yang dimulai sejak pendidikan anak usia dini akan sangat membantu anak dalam memperoleh pengalaman belajar bidang sains dan sosial.

Beberapa tema sasaran metode demonstrasi

\begin{tabular}{lr}
\multicolumn{2}{c}{ Penggunaan metode } \\
demonstrasi disertai dengan \\
penjelasan sering digunakan untuk
\end{tabular}

materi tentang cara membuat bentuk, bangunan dan cara menggunakan alat (Suyano dan Jihad: 2013:129)

. Oleh karena itu alternatif tema yang cocok menggunakan metode demonstrasi untuk anak usia dini antara lain adalah sebagai berikut:

1. Tema binatang Misalnya, dalam membentuk binatang dari plastisin/tanah liat, melipat binatang (sederhana), dan menggunting pola binatang.

2. Tema pakaian Misalnya, dalam kegiatan menggunting pola pakaian, atau menjahit (menusuk masuk keluar tali ke lubang yang telah disediakan di pinggir baju).

3. Tema kebersihan, kesehatan, dan keamanan.Misalnya, dalam mendemonstrasikan cara gosok gigi yang benar, atau cara makan.

4. Tema rumah

$$
\begin{aligned}
& \text { Misalnya, dalam } \\
& \text { mendemonstrasikan cara } \\
& \text { membuat bangunan dari balok, } \\
& \text { dalam menggambar bentuk }
\end{aligned}
$$


rumah, menusuk, atau merobek

bentuk rumah.

5. Tema kendaraan/transportasi Misalnya, dalam menggambar bentuk kendaraan, atau membentuk dari plastisin.

\section{RENCANA PERBAIKAN}

\section{A. Informasi Subjek Penelitian}

1.Lokasi Penelitian : TK Negeri $1 \quad$ Pembina

Gunungsitoli Selatan

Jalan Lasara Dusun III Desa

Ononamolo 1 Lot Kecamatan

Gunungsitoli Selatan Kota

Gunungsitoli

2. Waktu penelitian :

- Siklus I (14 Oktober 2014 s/d 31 Oktober 2014)-Siklus II (03 November 201 s/d21 November 2014)

3. Tema/sub tema : Binatang/binatang peliharaan

4. Kelompok :

"B" dengan jumlah anak 15 orang anak terdiri dari Perempuan 9 orang dan lakilaki 6 orang.

5. Menurut santrock (2009.39) usia 5 - 6 tahun adalah masa menengah dan akhir terkadang disebut " Tahun Sekolah Dasar"), anak - anak sudah menguasai keterampilan dasar membaca, menulis dan matematika, prestasi menjadi tema yang lebih utama dan pengendalian diri semakin baik. Dalam periode ini anak- anak berinteraksi dengan lingkungan sosial yang lebih luas dari keluarga mereka.

\section{Deskripsi Rencana Tiap Siklus}

\section{Rencana pelaksanaan}

$\underline{\text { Siklus I }}$

a. Perencanaan

- Menyusun RKH dan memeriksanya kembali dengan cermat.

- Menyiapkan media yang akan digunakan.

- Mempelajari tema yang disajikan kepada anak-anak.

- Mempersiapkan format penilaian.

b. Pelaksanaan Melaksanakan rancangan kegiatan yang telah disusun.

c. Observasi 
Mengamati proses

kegiatan anak pada saat melakukan pengisian

kolase.

d. Refleksi

Melakukan analisa data hasil pelaksanaan kegiatan.

Siklus II

a. Perencanaan

- Merefleksi siklus I

- Menyusun RKH dan memeriksanya kembali

- Menyiapkan media yang berukuran lebih kecil dari pada siklus I.

- Mempersiapkan format penilaian.

b. Pelaksanaan

Melaksanakan

rancangan kegiatan yang

telah disusun.

c. Observasi

Mengamati

proses

kegiatan anak pada saat melakukan pengisian kolase.

d. Refleksi
Melakukan analisa data hasil pelaksanaan kegiatan.

Langkah-langkah perbaikan Langkah-langkah pelaksanaan kegiatan mengisi kolase pada siklus I

a. Anak-anak terlebih dahulu diatur formasi dan posisi duduk mereka.

b. Guru menjelaskan kegiatan yang dilakukan.

c. Guru menunjukkan dan membagikan media pembelajaran kepaa anak-anak.

d. Guru menjelaskan nama dan jenis bahan yang digunakan untuk mengisi kolase.

e. Anak diberi kesempatan untuk bertanya apabila ada yang kurang dimengerti.

f. Anak melakukan pengisian kolase.

g. Guru memperhatikan proses kegiatan anak.

h. Guru memberi perhatian khusus bagi anak yang kurang semangat.

i. Guru mengumpulkan hasil kegiatan anak-anak. 
j. Guru menilai hasil kegiatan anak-anak.

Langkah-langkah pelaksanaan kegiatan mengisi kolase pada siklus II:

a. Guru membagi anak menjadi 3 kelompok dengan tugas dari setiap kelompok berbeda-beda.

b. Guru menjelaskan kegiatan yang akan dilakukan.

c. Guru mengajak anakanak bersama-sama memperhatikan kolase yang telah siap

d. Guru memberikan contoh cara mengisi kolase.

e. Guru menunjukkan dan membagikan media pembelajaran kepada anak-anak.

f. Guru menjelaskan nama dan jenis bahan yang digunakan untuk mengisi kolase.

g. Anak diberi kesempatan untuk bertanya apabila ada yang kurang dimengerti.

h. Anak melakukan pengisian kolase.

i. Guru memperhatikan proses kegiatan anak.

j. Guru memberi perhatian khusus bagi anak yang kurang semangat.

k. Guru mengumpulkan hasil kegiatan anakanak.

1. Guru menilai hasil kegiatan anak-anak.

\section{Rencana Pengamatan dan Pengumpulan \\ Data/Instrumen}

Untuk melihat sejauh mana kemampuan anak dalam kegiatan mengisi kolase maka saya menggunakan lembar instrumen untuk melakukan evaluasi.

Penilaian dengan lembar instrumen dilakukan 2 kali per siklus dengan bantuan 2 orang teman sejawat, masing-masing guru memegang 1 lembar observasi lalu mengamati anak dan mengisi lembar observasi 
tersebut. Dalam tahap penilaian ini ada aspek yang diamati yaitu:

- Mengisi kolase dengan rapi.
- Mengisi kolase tepat waktu

- Mengisi kolase secara mandiri

Tabel I .1

\begin{tabular}{|c|c|c|c|c|c|}
\hline \multirow[b]{2}{*}{ No } & \multirow{2}{*}{$\begin{array}{c}\text { Kegiatan/ } \\
\text { Uraian yang } \\
\text { Diamati }\end{array}$} & \multirow[b]{2}{*}{ Indikator } & \multicolumn{3}{|c|}{ Nilai } \\
\hline & & & SB & B & $\mathrm{KB}$ \\
\hline 1 & $\begin{array}{l}\text { Perencanaan } \\
\text { Kegiatan }\end{array}$ & $\begin{array}{l}\text { - Menyusun rencana dengan } \\
\text { pelaksanaan } \\
\text { - Media alat peraga yang } \\
\text { digunakan } \\
\text { - Keterampilan guru } \\
\text { - Kegiatan awal, inti, kegiatan } \\
\text { - } \text { akhir } \\
\text { - Pengamatan waktu } \\
\text { Pengaturan kelas }\end{array}$ & $\begin{array}{l}\checkmark \\
\checkmark \\
\checkmark\end{array}$ & $\begin{array}{l}\checkmark \\
\checkmark\end{array}$ & \\
\hline 2. & $\begin{array}{l}\text { Pelaksanaan } \\
\text { Kegiatan }\end{array}$ & $\begin{array}{l}\text { - Kesesuaian rencana dengan } \\
\text { Pelaksanaan } \\
\text { - Penampilan guru } \\
\text { - Cara guru memotivasi anak } \\
\text { - Minat anak melakukan kegiatan } \\
\text { - Hasil karya anak } \\
\text { - Penilaian yang dilakukan guru }\end{array}$ & $\checkmark$ & $\checkmark$ & $\begin{array}{l}\checkmark \\
\checkmark\end{array}$ \\
\hline
\end{tabular}

1. Kekuatan dan kelemahan tindakan perbaikan kegiatan pengembangan.

a. Kekuatan

- Guru menyemangati anak dengan memulai bernyanyi dengan judul "Lima ekor burung."

- Guru memotivasi anak untuk memperhatikan media yang akan digunakan. 
b. Kelemahan

- Guru agak kewalahan mengatur anak karena media pengisi kolase banyak yang tertumpah/tercecer.

2. Kekuatan dan kelemahan dalam merancang dan melakukan tindakan perbaikan kegiatan pengembangan.

a. Kekuatan

- Media kolase yang disediakan memancing ketertarikan anak-anak oleh karena beraneka ragam

- Dengan menggunakan media dapat membantu anak lebih bergairah dan dapat menimbulkan minat berkreatifitas.

- Anak-anak saling berlomba untuk menyelesaikan mengisi kolase dengan tepat waktu.

b. Kelemahan

- Fasilitas media yang disediakan tidak memadai - Formasi kelas yang membosankan bagi anak.

\section{Teknik Analisis Data}

Motorik halus anak usia dini perlu ditingkatkan, oleh karena itu pembelajaran kegiatan motorik halus harus menarik dan menyenagkan agar potensi anak dapat berkembang dengan baik, salah satu cara melalui kegiatan mengisi kolase. Subjek adalah anak TK Negeri 1 pembina Gunungsitoli Selatan kelompok B1 dengan jumlah peserta didik 15 anak. Teknik pengumpulan data yan digunakan meliputi observasi unjuk kerja dan dokumentasi. Teknik analisis data yang digunakan analisis data kualitatif (Darmono dan Hasan: 2002:34). Hasil analisis pada umumnya merupakan bagian intergal dari pengumpulan data di lapangan.

1. Analisis temuan yang terus menerus di lapangan khususnya dalam masalah yang diteliti dan juga dalam keseluruhan fenomena yang berkaitan dengan tujuan untuk mendapatkan tematema besar dan untuk mengembangkan konsep konsep.

2. Pengelompokan dan pengorganisasian data, segera mungkin setelah data 
diperoleh sehingga dapat menggunakan teknik kolase. membentuk peneliti dalam Berdasarkan hasil pengamatan yang memahami pada permasalahan atau tema fenomena yang teliti.

3. Evaluasi kualitatif tentang valiasi atau keterpelayanan data yang terus menerus.

\section{Kriteria Keberhasilan Tindakan}

Keberhasilan tindakan ini adalah apabila telah terjadi peningkatan sekitar $75 \%$ maka penelitian ini akan dihentikan. Namun apabila tidak terjadi peningkatan pada siklus pertama maka akan dilakukan siklus kedua, sampai terjadi peningkatan sekitar $75 \%$.

\section{HASIL DAN PEMBAHASAN}

Data penelitian yang diperoleh berupa data observasi hasil pengamatan dalam pembelajaran untuk masing - masing siklus. Data lembar observasi diambil dari observasi terhadap tindakan anak dalam proses pembelajaran yang digunakan untuk memenuhi proses meningkatkan minat belajar anak dengan pembelajaran yang

\section{A. Deskripsi Hasil Penelitian Perbaikan pembelajaran}

\section{Pra Siklus}

Dilaksanakan pada tanggal 13 Oktober 2014 dengan hasil penelitian dari 15 orang anak pada dimensi mengisi kolase dengan rapi sebanyak 9 orang anak berada pada posisi baik dan 6 orang anak pada posisi kurang baik. Pada dimensi 
JURNAL PENDIDIKAN USIA DINI

Volume 10 Edisi 1, April 2016

mengisi kolase tepat waktu dari 15

orang anak, 9 orang anak pada posisi

baik dan 6 orang anak pada posisi

kurang baik, sedangkan pada dimensi

mengisi kolase secara mandiri dari

15 orang anak, 4 diantaranya baik dan 11 orang anak kurang baik.

\section{Siklus Pertama}

Siklus pertama dilaksanakan pada hari selasa, 14 Oktober 2014. setelah dilaksanakan kegiatan pembelajaran yang menggunakan teknik kolase untuk meningkatkan perkembangan minat anak, bahwa selama ini kegiatan mengisi kolase dianggap hanya pelengkap suatu pelajaran bagi anak dan tidak dikaji bagaimana dengan efek yang ditimbulkan apabila tidak dipersiapkan sedemikian rupa. Media yang diberikan kepada anak tidak kreatif dan variatif sehingga pada akhirnya anak-anak dalam mengikuti pembelajaranpun tidak antusias, apa adanya bahkan ada yang malas ditambah dengan penyampaian tema yang disajikan kurang komunikatif masih ada yang belum mengerti dan tak bisa dipungkiri juga bahwa sebagian anak memang tidak mau memperhatikan gurunya.

\section{Siklus Kedua}

Siklus kedua ini dilaksanakan pada hari senin - Jumat / 03 November 2014 - 21 November 2014. Pada siklus kedua ini, perencanaan kegiatan dalam rencana kegiatan harian dilakukan mulai dari kegiatan awal, dengan formasi duduk yang dirubah dari kebiasaan selama ini, suasana penasaran yang sebelumnya telah diberitahu bahwa anak - anak akan menghadapi pekerjaan yang menarik dan menantang. Dan dimulai dengan sugesti yang biasa adalah bernyanyi “ Lima ekor burung” penjelasan berikutnya disampaikan juga bahwa anak - anak tetap duduk dalam kelompok dan dilakukan secara diskusi kecil yang akhirnya setiap individu mempunyai hasil karyanya, cara ini dilakukan agar kemampuan kerjasama anak maupun secara individu dalam kegiatan kolase lebih baik. Dan anak - anak memusatkan perhatian.

Sebelum melakukan kegiatan pada siklus II, peneliti menerangkan secara jelas setiap langkah - langkah kegiatan dan kemudian diberi contoh oleh peneliti semua kegiatan yang akan dilakukan. 
2. PEMBAHASAN TIAP

SIKLUS

\section{Pra Siklus}

Pra siklus telah dilaksanakan pada tanggal
13 Oktober 2014, dengan hasil persentase yang berada pada posisi kurang baik 53\% kurang baik dan baik berjumlah $47 \%$.

TABEL I.5

LEMBAR OBSERVASI - PRA SIKLUS

\begin{tabular}{|c|c|c|c|}
\hline NILAI & FREKUENSI & PERSENTASE & KETERANGAN \\
\hline * $\quad \mathrm{KB}$ & 8 & $53 \%$ & \\
\hline$* * \quad \mathrm{~B}$ & 7 & $47 \%$ & \\
\hline$* * * \mathrm{SB}$ & - & - & \\
\hline JUMLAH & 15 & $100 \%$ & \\
\hline
\end{tabular}

Keterangan :

$\mathrm{KB} *=$ Kurang Baik

$\mathrm{B} * *=$ Baik

$\mathrm{SB} * * *=$ Sangat Baik

DIAGRAM PRA SIKLUS

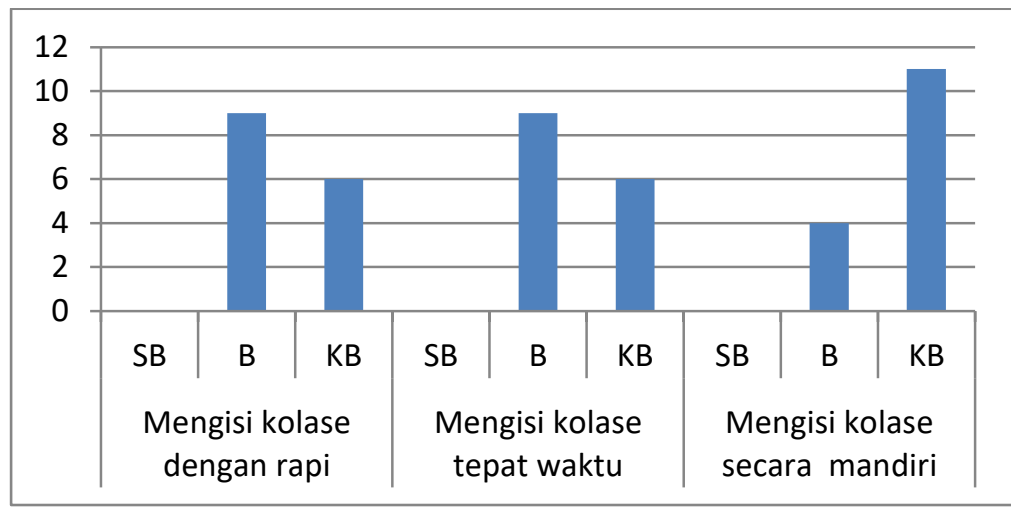

Pada dimensi mengisi

kolase dengan rapi, tidak ada anak yang mendapat nilai sangat baik (SB). 9 anak mendapat nilai baik (B) dan 6 anak mendapat nilai kurang baik (KB). Pada dimensi mengisi kolase tepat waktu tidak ada anak mendapat niai sangat baik (SB). 9 anak mendapat nilai baik (B) dan 6 anak mendapat nilai kurang baik (KB). Dimensi mengisi kolase secara mandiri, tidak ada anak mendapat nilai sangat baik (SB), 4 anak mendapat nilai baik (B) dan 11 anak mendapat nilai kurang baik (KB).

\section{Siklus 1}


JURNAL PENDIDIKAN USIA DINI

Volume 10 Edisi 1, April 2016

Pada siklus pertama

pembelajaran meningkatkan

minat belajar anak melalui

kegiatan kolase sebagai berikut:

Refleksi :

Berdasarkan hasil analisi data,

diketahui bahwa $46.68 \%$ anak mendapat nilai kurang baik, $26.66 \%$ anak mendapat nilai Baik dan $26.66 \%$ anak mendapat nilai sangat baik.

TABEL I.5

LEMBAR OBSERVASI - SIKLUS I

\begin{tabular}{|c|c|c|c|}
\hline NILAI & FREKUENSI & PERSENTASE & KET \\
\hline * $\mathrm{KB}$ & 7 & $46.68 \%$ & \\
\hline$* * \quad \mathrm{~B}$ & 4 & $26.66 \%$ & \\
\hline$* * * \mathrm{SB}$ & 4 & $26.66 \%$ & \\
\hline JUMLAH & 15 & $100 \%$ & \\
\hline
\end{tabular}

Keterangan :
$\mathrm{KB} *$
$\mathrm{B} * *$
$=$ Kurang Baik
$\mathrm{SB} * * *$
$=$ Baik
= Sangat Baik

DIAGRAM SIKLUS I

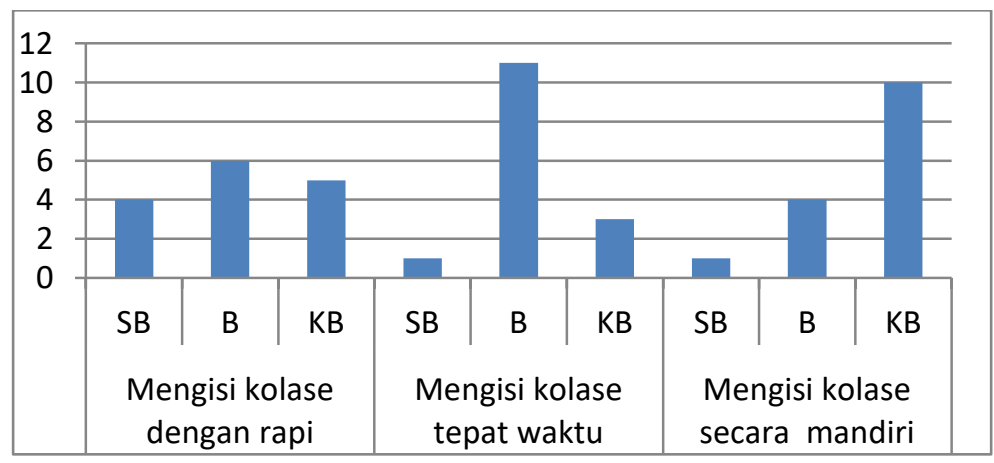


Pembahasan :

Pada dimensi mengisi kolase dengan rapi 4 orang anak yang mendapat nilai Sangat Baik (SB), 6 anak mendapat nilai Baik (B) dan 5 anak mendapat nilai Kurang Baik $(\mathrm{KB})$. Dimensi mengisi kolase tepat waktu 1 anak mendapat nilai Sangat

Baik (SB), 11 anak mendapatkan nilai Baik (B) dan 3 anak mendapat nilai Kurang Baik (KB). Dimensi mengisi kolase secara mandiri 1 orang anak mendapat nilai Sangat Baik (SB), 4 anak mendapat nilai Baik (B) dan 10 orang anak mendapat nilai Kurang Baik (KB).

Bedasarkan hasil analisa inplementasi dengan kegiatan kolase dalam meningkatkan minat anak belajar pada siklus pertama 3 . pelaksanaan kegiatan berjalan dengan lancar walaupun masih banyak anak-anak yang belum menyelesaikannya dengan baik. Dalam hal ini anak-anak sudah mau melakukan kegiatan seperti mengisi kolase dengan rapi yang harus disesuaikan dengan gambar. Walupun masih ada anak yang belum dapat menyelesaikan dengan baik.
Pada mulanya perencanaan pelaksanaan kegiatan kolase dengan menggunakan bahan plastik bekas jajanan dilaksanakan secara klasikal. Namun setelah di ujicobakan kegiatan ini terdapat kelemahan.

Anak-anak menjadi rebutan dalam mengambil guntingan plastik bekas jajanan sehingga anak sulit untuk membuat dengan baik. Maka dirubah tekniknya dengan membuat kelompok, anak duduk dalam kelompok dan melakukan kegiatan kolase dalam kelompok kecil lebih mudah untuk memusatkan perhatian dalam mencari warna-warna yang tepat dari guntingan plastik bekas jajanan.

\author{
Siklus Kedua \\ Pada siklus kedua pembelajaran \\ meningkatkan minat belajar \\ anak \\ melalui kegiatan kolase sebagai \\ berikut : \\ Refleksi : \\ Siklus kedua dilaksanakan pada \\ tanggal 03 November 2014 - 21 \\ November 2014.
}


TABEL I.6

LEMBAR OBSERVASI - SIKLUS II

\begin{tabular}{|c|c|c|c|}
\hline NILAI & FREKUENSI & PERSENTASE & KET \\
\hline$* \quad \mathrm{~KB}$ & - & - & \\
\hline$* * \mathrm{~B}$ & 3 & $20 \%$ & \\
\hline$* * * \mathrm{SB}$ & 12 & $80 \%$ & \\
\hline JUMLAH & 15 & $100 \%$ & \\
\hline
\end{tabular}

Keterangan :

$\mathrm{KB} *=$ Kurang Baik

$\mathrm{B} * *=$ Baik

$\mathrm{SB} * * *=$ Sangat Baik

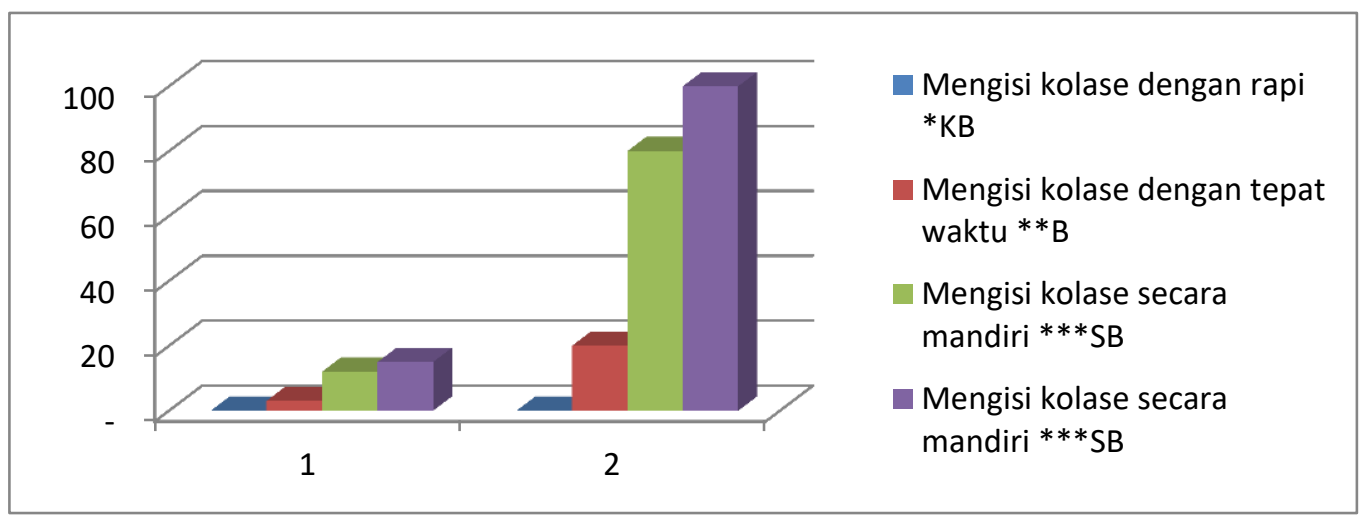

Diagram Siklus 1 dan 2

\section{Pembahasan :}

Pada dimensi mengisi kolase dengan rapi 15 anak mendapat nilai Sangat Baik (SB), 0 anak mendapat nilai Baik (B) dan 0 anak mendapat nilai Kurang Baik (KB). Dimensi mengisi kolase tepat waktu 12 anak mendapat nilai Sangat Baik (SB), 3 anak mendapat

nilai Baik (B) dan tidak ada anak mendapat nilai Kurang Baik (KB). Dimensi mengisi kolase secara mandiri 6 orang Sangat Baik (SB), 9 anak mendapat nilai Baik (B) dan tidak anak mendapat nilai Kurang Baik (KB).

Pada siklus 2 ini kelihatan perencanaan yang telah dipersiapkan sesuai dengan yang dibutuhkan. Kegiatan yang dilakukan anak sudah sesuai dengan kegiatan kolase dari bahan plastik bekas jajanan. Anakanak aktif dan semangat dalam melakukan kegiatan kolase ini, menempelkannya, menyusunnya sambil bersanjak. Anak-anak 
berlomba untuk menjadi yang terbaik. Jadi dapat disimpulkan bahwa kegiatan ini jauh lebih baik dari pada yang biasa dilakukan, dan anak-anak merasa senang dan termotivasi begitu juga gurunya.

Pada siklus 2 ini peneliti sudah mudah dalam menyimpulkan data keberhasilan anak karena pada umumnya anak sudah mampu melaksanakan kegiatan kolase dengan guntingan plastik bekas jajanan.

\section{Pra Siklus, Siklus I dan Siklus} II

Setelah melakukan pra siklus, siklus I dan II peneliti menyimpulkan bahwa telah terjadi peningkatan yang signifikan dari siklus I ke siklus II. Gambaran awal sekitar 53\% anak termasuk kurang baik, sebanyak $47 \%$ termasuk kriteria baik serta tidak ada yang masuk pada kriteria sangat baik.

Pada siklus I 46,66\% anak termasuk kurang baik, sebanyak 26,66\% termasuk kriteria kurang baik serta $26,66 \%$ sangat baik. Sedangkan pada siklus II bahwa 20\% anak termasuk kriteria baik dan $80 \%$ anak termasuk pada kriteria baik dan sudah tidak ada dengan kriteria kurang baik.

Apabila ditampilkan dalam bentuk diagram hasilnya sebagai berikut :

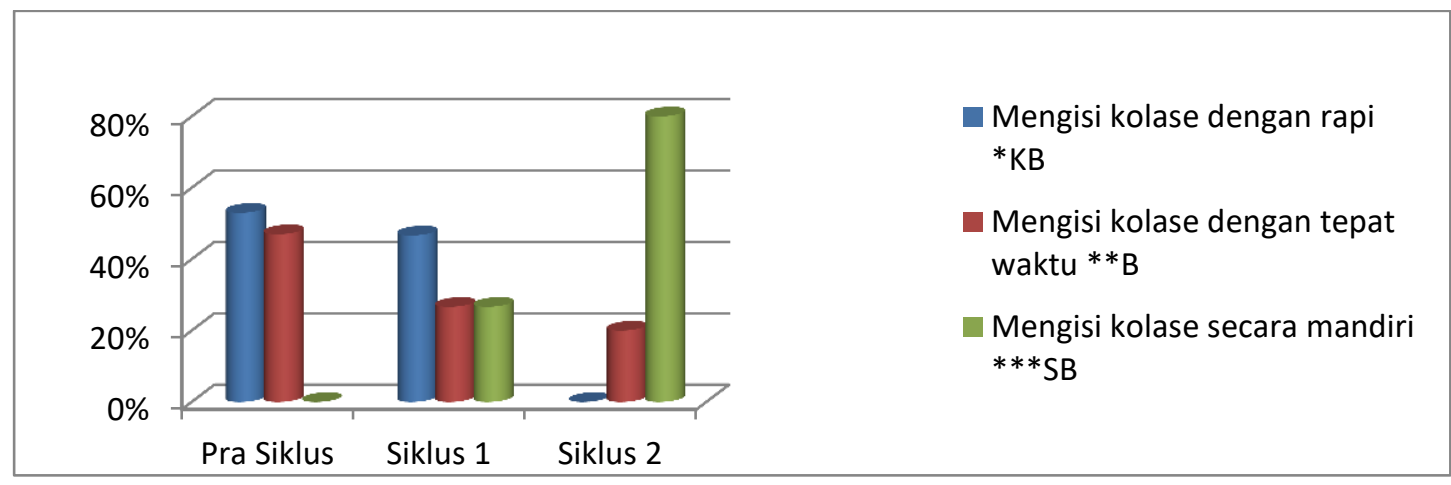


JURNAL PENDIDIKAN USIA DINI

Volume 10 Edisi 1, April 2016

Perkembangan motorik halus, seperti jari tangan dan indera memiliki milestone atau tolak ukur perkembangan anak sehingga dapat dipergunakan untuk melihat tahap perkembangan anak sesuai dengan usia. Perkembangan fisik pada tahap 2-3 tahun akan berkembang sedemikian rupa sehingga anak mampu melakukan aktivitas motorik yang lebih beragam. Keberagaman aktivitas motorik anak di tahap usia ini pun dipengaruhi oleh perkembangan area corteks di otak

Pada siklus I 69,9\%, siklus II $81,25 \%$, sedangkan hasil belajar anak dalam mengisi kolase, persentasi kemampuan anak masuk di bawah ketuntasan. Pada siklus I ke siklus II kemampuan anak menalami peningkatan yaitu 11, 33\%. Berdasarkan hasil tersebut di atas, dapat disimpulkan bahwa penerapan langkah-langkah metode demonstrasi dapat meningkatkan kemampuan motorik halus khususnya dalam mengisi kolase. Berdasarkan penelitian ini disarankan agar guru menerapkan langkah metode pembelajaran yang inovatif, menarik dan menyenangkan dala kegiatan pembelajaran sehari-hari di kelas yang memungkinkan anak untuk mengembangkan kepekaan indera dan motorik sehingga anak mampu mengkoordinasikan apa yang diinginkan gerakan yang ia lakukan (Papalia, 2008).

Motorik halus anak adalah kemampuan fisik yang melibatkan otot-otot yang lebih kecil dan koordinasi mata, tangan pada usia carly childhood seperti kegiatan melipat, mewarnai, melukis, menggunting, dan menjiplak. (Marison, 2009).

untuk mencapai hasil yang maksimal.

\section{KESIMPULAN DAN SARAN}

\section{A. Kesimpulan}

1. Dalam rangka pembelajaran aktif kreatif dan menyenangkan (PAKEM) dibutuhkan kreatifitas dari guru untuk menciptakan suatu sarana/media yang mendukung keberhasilan kegiatan belajar mengajar yang optimal.

Salah satu upaya untuk merangsang minat anak didik yang aktif, kreatif dan efektif yaitu dengan menggunakan 
Meningkatkan Minat ...

Natalia Purba, Mariana Larosa

media kolase yang

\section{DAFTAR PUSTAKA}

menyenangkan.

2. Disamping media yang menyenangkan guru dituntut mengkaji ukuran media pembelajaran yang sesuai dengan karakter anak-anak.

\section{B. Saran}

a. Keberhasilan suatu program menuntut adanya peran dari institusi yang berwenang misalnya Kepala Sekolah atau Yayasan sehingga diperlukan orang absolut dan tidak kaku, dalam memberikan fasilitas dan kesempatan seluas-luasnya kepada guru untuk selalu melakukan inovasi dalam berbagai pendekatan pembelajaran, diharapkan untuk ini Kepala Sekolah bertindak sebagai dinamisator dan motivator.

b. Para guru adalah satu-satunya ujung tombak untuk melakukan inovasi-inovasi dalam meningkatkan kualitas pendidikan kepada anak didik.

Badru Zaman, dkk (2010), Media dan Sumber Belajar TK, Jakarta-Universitas Terbuka;

Carmer, Kathy And Maureen Murphy, Brain Power: Aktivitas Pintar Untuk Prasekolah (2006), Jakarta: Erlangga

Darmono dan Ani M Hasan, Menyelesaikan Skripsi Dalam 1 Semester (2002), Jakarta: Grasindo

DjamarahSyaiful Bahri,(2000), Guru Dan Anak Didik Dalam Interaksi Edukatif, Jakarta: RiekaCipta.

Habibi, Muazar, Analisis Kebutuhan Anak Usia Dini: Buku Ajar S1 PAUD (2015) Jakarta: Deepublish

Johnson, Elaine B, Contextual Teaching And Learning: What Is And Why It's Here To Stay (2002), USA: Crown Press

Lucy, Bunda. MendidikAnak Sesuai Dengan Minat Bakat Anak(2010) Jakarta: Agromedia Pustaka

Morrison, George S. Early Child Dhood Education Today (2009)

Mulyani, Yani dan Juliska Garcinia, Kemampuan Fisik, Seni dan Managemen Diri (2007) Jakarta: Elex Media Komputindo.

Papalia, Olds dan Feldman. Psikologi Perkembangan Anak, Jakarta. Universitas Terbuka 2006;

Siti Aisyah, dkk (2012), Perkembangan dan Konsep Dasar Pengembangan Anak Usia, Banten-Universitas Terbuka;

Sri Tatminingsih, M.Pd dkk (2013), Panduan

Pemantapan 
JURNAL PENDIDIKAN USIA DINI

Volume 10 Edisi 1, April 2016

Kemampuan Profesional, Edisi 2, Universitas Terbuka;

Supangkat, Jim Dan., Rizki A Zaelani, (2006), IkatanSilangBudaya: SeniSeratBinarulAnas.

Bandung: Art Fabrics.

Suyanto, dan Asep Jihad, Menjadi Guru Professional: Startegi Meningkatkan Kualifikais Dan Kualitas Guru Di Era Global (2013) Jakarta: Erlangga

Winda Gunarti, S.Pd dkk (2012), Metode Pengembangan Perilaku dan Kemampuan Dasar Anak Usia Dini, Banten-Universitas Terbuka;

Wahdiyani, Nur Azmina dan Zuharni, AW (2010) Buku Pintar: Membaca Dan Menulis Metode Cepat, Mudah Dan Menyengkan, Jakarta: Kawah Media 